\title{
MENGUNGKAP MOTIF DI BALIK PELAKSANAAN CORPORATE SOCIAL RESPONSIBILTY PERUSAHAAN PADA PT XYZ di MAKASSAR \\ Bertha Beloan ${ }^{1}$ \\ Universitas Kristen Indonesia Paulus \\ bertha@ukipaulus.ac.id
}

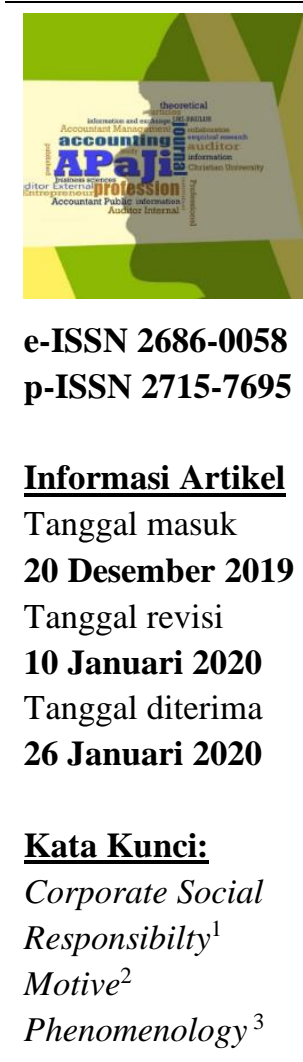

\begin{abstract}
The diversity of motives cloring the corporate social responsibility conducted by the is attractive to be explored currently. The aim of the research was to reveal the motive behind the implementation of company's corporate social responsibilty (CSR) at PT XYZ of Makassar. The reseacrh used interpretative paradigm with phenomenological analysis. Phenomenological methodology was expected to be able to give more information on the implementation of CSR in order to be understood and run by the company as well as the motive behind the implementation of CSR. The results of the research indicate that CSR done by the company is originally a tradition coming from moral responsibility which then shifts toward capitalist. This is indicated by the exchange of motive and image motive that characterizes the implementation of CSR done by the company. The exchange motive based on the term "I give, so that you give" is the most dominant motive to maximize profits.
\end{abstract}

\begin{abstract}
Abstrak: Beragamnya motif yang mewarnai pelaksanaan Corporate Social Responsibilty (CSR) yang dilakukan oleh perusahaan merupakan hal yang menarik untuk dieksplorasi saat ini. Penelitian ini bertujuan untuk mengungkap motif di balik pelaksanaan Corporate Social Responsibilty (CSR) perusahaan yang ada di PT XYZ di Makassar. Penelitian ini menggunakan paradigma interpretif dengan metode analisis fenomonologi. Metode tersebut diharapkan mampu menggali lebih dalam informasi terhadap pelaksanaan CSR yang dipahami dan yang dijalankan perusahaan serta motif di balik pelaksanaan CSR tersebut. Hasil penelitian menunjukkan bahwa pelaksanaan CSR yang dilakukan oleh perusahaan yang semula adalah tradisi yang lahir dari tanggung jawab moral, kini bergeser kea rah kapitalis. Hal tersebut terlihat dari motif pertukaran dan motif pencitraan yang mewarnai pelaksanaan CSR yang ada dilakukan perusahaan. Motif pertukaran yang menganut istilah "saya memberi supaya engkau memberi" adalah motif yang paling dominan untuk memaksimalkan keuntungan.
\end{abstract}



\section{PENDAHULUAN}

Catatan sejarah jelas mengatakan bahwa perusahaan berdiri pada mulanya untuk kepentingan umum, untuk memenuhi kebutuhan masyarakat, untuk memberikan jasa pelayanan bagi masyarakat umum. Perusahaan tersebut dipandang sebagai kepanjangan tangan dari pemerintah, melakukan bisnis pemerintah baik yang berupa lembaga pemerintahan maupun publik. Kemudian perusahaan berubah, bukan lagi melayani kepentingan publik, melainkan kepentingan pribadi, (Estes, 2005). Baru pada abad ke-19 dibuat suatu komitmen yang memberikan keuntungan bagi para pemegang saham sebagai tujuan utama perusahaan. 
Dalam peroses tersebut apa yang semula merupakan manajemen perusahaan untuk melayani kepentingan umum menjadi sekedar tindakan yang menuruti selera pribadi (Estes, 2005).

Pergeseraan ini membuat pihak perusahaan hanya sibuk memikirkan bagaimana memperoleh profit yang sebesar-besarnya. Ini berarti bahwa perusahaan dipandang sebagai organisasi yang hanya memiliki misi ekonomi semata, khususnya misi mencari laba setinggitingginya. Hal ini seperti diungkap oleh Friedman dalam Robins (2005), "The business of business is to maximise profits, to earn a good return on capital invested and to be good corporate citizen obeying the law- no more and no less".

Di keluarkannya UU No.40 Tahun 2007 tetang Perseroan Terbatas, melalui pasal 74, mengatur secara khusus tentang kewajiban perusahaan untuk melaksanakan tanggungjawab sosial dan lingkungannya membuat perusahaan pada umumnya menjalankan CSR atas dasar memenuhi kewajiban kontraktual, dalam hal ini mematuhi peraturan bahkan sebagian menggangap bahwa CSR adalah beban bagi perusahaan yang harus dikeluarkan yang berdampak pada penurunan kinerja keuangan, seperti yang diungkap oleh Juholin (2004), bahwa CSR lebih cenderung sebagai orientasi bisnis. Sangat berbeda dengan beberapa penelitian seperti yang diungkap Graafland \& Bert (2006), bahwa moral sebagai motif yang lebih kuat kontribusinya terhadap CSR dibandingkan finansial dan penelitian Joyner \& Payne (2002), bahwa etika yang baik dapat memiliki pengaruh ekonomi positif pada kinerja perusahaan. Hal ini didukung oleh hasil penelitian Branco \& Rodriques (2008), Mereka berpendapat bahwa "ada sesuatu" di dalam konsep CSR yang membuat perusahaan tidak terbebani melainkan menerima dan mempraktikkan CSR secara sukarela. Selaras dengan penelitian Gulsevim \& Gokhan (2009), menyebutkan bahwa, program Corporate Social Responsibility yang dilakukan sebagai upaya meningkatkan reputasi sosial yang bertujuan untuk meningkatkan nilai (value) perusahaan.

Mengungkap lebih dalam akan motif perusahaan dalam melaksanakan tanggung jawab sosial mereka merupakan hal yang menarik dilakukan di tengah beragamnya motif yang ada, selain itu menjadi semakin menarik bahwa fenomena yang ada di mana pihak perusahaan mengklaim sudah melakukan tanggung jawab sosial yang mereka sebagai bentuk tanggung jawab moral sementara beberapa karyawan malah berdemo menuntut hak mereka. Penelitian ini dimaksudkan untuk mengungkap apa motif di balik pelaksanaan akan tanggung jawab sosial yang ada di PT XYZ di Makassar. Apakah hanya sebuah kewajiban kontraktual belaka sebagai pencitraan ataukah memang sebuah komitmen moral terlepas dari untung atau rugi.

\section{METODE PENELITIAN}

\section{Lokasi dan Rancangan Penelitian}

Penelitian ini dilakukan di PT XYZ di Makassar yang merupakan salah satu perusahaan indutri kayu lapis. Selaras dengan tujuan yang ingin dicapai, maka metode dengan pendekatan kualitatif dianggap tepat untuk digunakan dalam penelitian ini. Penelitian kualitatif bertujuan untuk memahami realitas sosial dan melihat realitas tersebut secara apa adanya. Hal ini seperti yang diungkapkan oleh Santana (2010), bahwa penelitian kualitatif menekankan pada pemahaman terhadap realitas sosial. Penelitian kualitatif ditujukan untuk memahami fenomena sosial dari sudut pandang atau perspektif partisipan.

Paradigma yang digunakan dalam penelitian ini adalah paradigma interpretif, dengan fenomonologi sebagai metode penelitian. Burrel \& Morgan (1979), mengatakan bahwa inti dari 
paradigma interpretif adalah memahami bentuk fundamental dari dunia sosial pada tingkat pengamatan sosial dan tingkat pengalaman subjektif seseorang yang bersifat nominalis, antipositivis, voluntarisme dan iedografis. Pada dasarnya, penelitian kualitatif interpretif berusaha untuk memberi penekanan pada bahasa dan makna terkait dengan pemahaman interpretatif atas tindakan manusia. Paradigma interpretif memandang realitas sosial sebagai sesuatu yang holistik, kompleks, dinamis dan penuh makna serta lebih menekankan pada makna atau interpretasi seseorang terhadap sebuah simbol. Dengan menggunakan paradigma interpretif diharapkan dapat mengungkap motif di balik pelaksanaan Coorporate Social Responsibility yang ada di PT XYZ di Makassar.

\section{Informan}

Dalam penelitian kualitatif, tidak menggunakan populasi karena penelitian kualitatif berangkat dari suatu situasi sosial tertentu, seperti yang diungkapkan oleh Sugiyono (2012), bahwa penelitian kualitatif tidak menggunakan istilah populasi, tetapi social situation atau situasi sosial yaitu kesinambungan antara tempat (place), pelaku (actors), dan aktivitas (activity) yang berinteraksi secara sinergis. Pada situasi sosial peneliti dapat mengamati secara mendalam aktivitas (activity) orang-orang (actors) yang ada pada tempat (place) tertentu.

Untuk memudahkan memasuki setting penelitian, maka peneliti mula-mula akan berkenalan secara umum kepada bagian yang mengatur mengenenai kegiatan sosial di perusahaan tersebut tersebut melalui key informant. Selanjutnya kepada calon subyek penelitian akan diadakan pendekatan secara pribadi melalui Guide person. Setelah kehadiran peneliti dirasa telah diterima dengan baik, barulah akan memulai mengumpulkan data yang diperlukan, tentunya dengan tetap membina hubungan baik yang telah terjalin.

Informan dalam penelitian ini terdiri dari Direktur Operasional, Jajaran Manager, Kepala Bagian. Keseluruhan informan ini merupakan informan kunci yang peneliti anggap relevan dan dapat memberikan informasi yang dibutuhkan terkait tema penelitian ini. Informan kunci merupakan orang-orang yang bersentuhan langsung dalam pengambilan keputusan, penyusunan kinerja, pertanggungjawaban dan memiliki pengetahuan dan pemahaman yang luas mengenai objek peneliti.

\section{Pengumpulan Data}

Dalam rangka mengumpulkan data, peneliti menggunakan tiga teknik pengumpulan data, yaitu dengan teknik observasi, indepth interview dan dokumentasi. Observasi peneliti lakukan sejak pertama kali memasuki situs penelitian hingga penelitian ini berakhir. Proses wawancara dalam penelitian ini direkam dengan menggunakan alat perekam. Peneliti juga menambahkan beberapa catatan lapangan dan catatan penting lainnya yang sangat membantu memperoleh data yang lebih akurat. Untuk membantu peneliti tetap fokus pada tujuan yang ingin dicapai, peneliti menyiapkan catatan mengenai poin-poin penting yang akan peneliti kemukakan kepada informan. Catatan tersebut semacam Interview schedule yang melampirkan mengenai pokok-pokok yang akan ditanyakan. Membuat fieldnote (catatan lapangan), melakukan rekaman wawancara, dan transkrip hasil wawancara sangat membantu dalam proses pengumpulan data dalam penelitian ini. Pengumpulan data melalui dokumentasi dalam penelitian ini, diperoleh, catatan mengenai sejarah berdirinya PT XYZ, Company Profile, dan lain-lain.

\section{Teknik dan Analisis Data}


Teknik analisis data mengacu pada model interaktif yang dikembangkan oleh Miles \& Huberman (1984), yang prosesnya terdiri atas koleksi data, reduksi data, penyajian data dan pengambilan kesimpulan/verifikasi. Proses analisis data dilakukan secara terus menerus selama penelitian berlangsung. Seperti yang diungkapkan oleh Miles \& Huberman (1984), bahwa aktivitas dalam analisis data kualitatif dilakukan secara interaktif dan berlangsung secara terus menerus sampai tuntas, hingga datanya jenuh. Data yang jenuh ditandai dengan tidak diperolehnya lagi data atau informasi baru.

Terkait dengan metode penelitian yang digunakan, yaitu fenomonologi, maka analisis data yang dilakukan juga dengan mengikuti kaidah dalam penelitian fenomonologi Husserl yaitu dengan melihat dari sisi noema dan noesis. Noema dan noesis merupakan konsep penting dalam melakukan analisis data fenomenologi. Menurut Edmund Husserl seperti yang dikutip oleh Mamulati (2016), Noema itu faithfully and in the light of perfect self-evidence, makna dari objek itu sendiri dan sesuatu yang diterima oleh panca indera manusia sedangkan noesis seperti menurut Edmund Husserl seperti yang dikatakan oleh Moeryadi (2009), merupakan bahan dasar pikiran dan jiwa (mind and spirit) manusia atau pemberian makna atau interpretasi atas suatu objek. Dengan begitu, maka proses analisis seluruhnya dalam penelitian ini meliputi lima tahapan, yaitu mengorganisir data, reduksi data, penyajian/display data, noema dan noesis, serta verifikasi/kesimpulan.

\section{HASIL PENELITIAN}

\section{CSR : Sebuah Pandangan Noema Atas Tradisi Perusahaan}

PT XYZ yang awalnya merupakan perusahaan Jepang. Tradisi dan nilai- nilai budaya yang dibawa oleh pendirinya yang merupakan warga negara Jepang tercerminkan di dalam PT XYZ. Menurut bapak BD yang direkrut pada masa Jepang mengatakan bahwa apa yang dilakukan adalah semata-mata karena tradisi.

“...sebenarnya kalau berbicara mengenai tanggungjawab sosial itu sangat luas, melibatkan masyarakat, lingkungan, karyawan, perusahaan,pemerintah,dll. Tapi yang ingin saya katakan di sini akan tanggungjawab sosial kepada masyarakat. Sebenarnya tanggungjawab sosial di kalangan masyarakat kita sudah ada sejak lama (sejak perusahaan ini berdiri) tetapi pelaksanaan tidak dituangkan secara tertulis namun hanya berbentuk tradisi, contoh sederhana perayaan 17 agustus yang melibatkan masyarakat dan pemberian takjil puasa kepada karyawan..."

Petikan wawancara di atas mengindikasikan bahwa jauh sebelum adanya ketetapan undang-undang mengenai kewajiban pelaksanaan CSR, perusahaan telah menerapkan program kegiatan yang serupa. Hal ini dibuktikan di mana perusahaan ini berdiri pada tahun 1982 dan sudah memulai dengan hal-hal yang sederhana seperti pemberian sumbangan untuk acara keagamaan atau perbaikan jalan untuk akses masyarakat lokal. Salah satu yang menarik adalah pemberian takjil puasa kepada para karyawan. Tradisi ini kemudian terus di jalankan hingga saat ini. Perbedaan yang paling mendasar, saat ini perusahaan menerapkan "tradisi" tersebut dalam kerangka program CSR perusahaan. Meskipun sebatas program yang merupakan tradisi perusahaan, dan hanya bersifat kedermawanan sosial, namun hal ini tetap menjadi salah satu 
faktor yang menjadi pertimbangan bagi perusahaan untuk menerapkan program yang substansinya dipandang sebagai bentuk CSR.

Dalam konteks tanggung jawab sosial (CSR) ada tanggung jawab moral untuk memperbaiki atau sebaliknya untuk memberi ganti rugi atas kerusakan apapun yang ditimbulkan. Ini yang kemudian penulis lihat dipermukaan bahwa perusahaan memahami tanggung jawab sosial mereka pada ranah moral, Moral dalam tanggung jawab sosial lebih mengarah pada tindakan lahiriah yang didasarkan sepenuhnya dari sikap batiniah, sikap inilah yang dikenal dengan "moralitas" yaitu sikap dan perbuatan yang betul-betul tanpa pamrih, dan hal inilah yang sekilas penulis lihat. Selaras dengan yang disampaikan oleh Bapak Direktur Operasional PT XYZ, Beliau mengatakan:

“...nilai-nilai moral bukan hanya sebuah ucapan saja, melainkan sebuah pembuktian. Kita baru tahu dan sadar ketika perusahaan mampu bertahan sampai saat ini meskipun diterjang badai dunia usaha. Perusahaan yang dulunya di bawah manajemen Jepang yang sangat memperhatikan para pekerjanya dan tanggung jawab sosialnya tetap dipertahankan sampai saat ini. Perlu diketahui bahwa sistem lahir dari nilai perusahaan dalam hal ini nilai moral sehingga berubah menjadi budaya perusahaan...."

CSR memandang perusahaan sebagai agen moral dengan parameter keberhasilan perusahaan dengan mengutamakan prinsip-prinsip moral dan etika yang akan memberikan manfaat untuk masyarakat. Artinya bahwa, dengan atau tanpa aturan hukum, sebuah perusahaan harus menjunjung tinggi moralitasnya. Hal yang dilakukan perusahaan ini sungguh menarik, karena sudah menjadi kebiasaan yang sudah ada sejak perusahaan ini berdiri jauh sebelum undang-undang akan CSR di sahkan di Indonesia.

Pelaksanaan tanggung jawab sosial perusahaan yang awalnya merupakan sebuah tradisi kemudian berubah menjadi sebuah program tahunan perusahaan untuk tetap melaksanakan tanggung jawab sosial perusahaan.

\section{Kontribusi Perusahaan : Motif Pertukaran Menjadi Warna yang Paling Dominan.}

PT XYZ dalam melaksanakan program CSR mereka yang awalnya merupakan sebuah tradisi dimaknai sebagai tanggung jawab moral. Apa yang mereka lakukan yang nampak di mata masyarakat adalah sebuah bentuk kebaikan. Perusahaan ingin membuktikan bahwa mereka juga memiliki rasa empati kepada masyarakat yang ada di sekitar perusahaan. Sayangnya apa yang dilakukan tidak murni dari dalam hati. Penulis melihat ada asas pertukaran (exchange). Pertukaran yang di maksud adalah adanya pertimbangan untung dan rugi dalam melakukan kegiatan sosialnya. "Do ut des" saya memberi supaya engkau memberi. Motif pertukaran ini yang mewarnai pelaksanaan CSR dalam PT XYZ. Hal ini tercermin dari pernyataan salah satu warga yang tinggal di dekat area logpond:

“...di kasiki memang bantuan sembako dari perusahaan, lumayan juga dari pada tidak ada" ..." tapi kan kita juga bantu ki juga jaga kayu-kayunya yang disimpan di sungai".

“...iye, dulu itu kadang hilangki kayunya, ndak tau juga. Mungkin hanyutki di sungai, karena ada itu kayu yang tenggelam jadi harus ki di ikat. Nah kita mi itu yang juga bantu-bantu untuk ikat kayu-kayu yang tenggelam itu" 
Pernyataan di atas diamini oleh salah satu pegawai logpond:

“...nah cocok mi itu dia bantu-bantuki, karena mereka itu dapat ki bantuan sembako dari perusahaan. Masa sudah dikasi bantuan nah tidak mau bantu-bantu jaga itu tongmi guna-gunanya."..."ndak pernahmi hilang tawwa kayu di sini, kecuali memang pernah hilangki 2 karena pas banjir lepaski dari ikatannya"

Komentar di atas merupakan salah satu bentuk dari asas pertukaran yang dikemukakan oleh Peter M.Blau yang berangkat dari asumsi do ut des (saya memberi supaya engkau memberi). Mungkin secara tidak sadar apa yang terjadi dari bentuk pemberian sembako adalah harga yang harus di bayar oleh warga tesebut berupa waktu dan tenaga yang di tukarkan dengan sembako (1 dos mie instan dan 1 liter minyak goreng). Kontribusi perusahaan berupa pemberian sembako kepada masyarakat yang ada di bantaran sungai Tallo adalah bentuk balas jasa atas waktu dan tenaga yang diberikan oleh masyarakat untuk mengurangi dampak kerugian atas hilangnya kayu-kayu yang ada di area logpond.

Berkaitan dengan program CSR perusahaan di atas dalam pemberian bantuan sembako yang diwarnai dengan asas pertukaran, menarik untuk disandingkan dengan salah satu program yang lain yaitu program peduli lingkungan 1 untuk 5 kehidupan yang juga diwarnai oleh asas pertukaran. Berikut kutipan wawancara dengan bapak AS:

“...kalau saya melihat bahwa inti tanggung jawab sosial perusahaan itu adalah apa yang perusahaan keluarkan dan apa yang didapatkan. Mulai tahun 2006 lalu kami sudah membuat program CSR untuk menjaga kelangsungan lingkungan yaitu program 1 untuk 5 kehidupan, artinya bahwa untuk satu kayu gelondongan yang kami produksi menjadi lembaran tripleks kami akan ganti dengan menanam pohon 5 untuk kehidupan anak cucu kedepan."

Lebih lanjut beliau mengatakan:

“...program yang kami jalankan ini adalah untuk mengganti apa yang sudah kami ambil, jadi sudah sepatutnya program penanaman pohon ini kami fokuskan ke areaarea pemasok bahan baku. Seperti yang sudah saya katakan sebelumnya bahwa kami mengganti apa yang kami ambil"..." ya saya rasa wajar saja kalau bibit yang kami berikan itu adalah jenis bibit dari kayu yang kami produksi".

Pernyataan di atas memperlihatkan bahwa bibit kayu jati dan sengon yang diberikan kepada masyarakat lewat program 1 untuk 5 kehidupan adalah salah satu program untuk mengembalikan kerusakan alam dari penebangan pohon. Niat perusahaan seperti pernyataan bapak AS di atas sangat baik dan merupakan tanggung jawab moral, seperti ungkapan bahwa kita tidak mewarisi bumi ini dari nenek moyang kita, tetapi kita meminjamnya dari anak cucu kita. Jadi, sudah selayaknya jika apa yang kita pinjam kemudian kita kembalikan dan apa yang sudah kita rusak sudah selayaknya kita perbaiki. Namun yang penulis lihat apa yang dilakukan adalah untuk kepentingan bisnis (ada asas pertukaran di dalamnya) lebih cenderung sebagai orientasi bisnis. Bibit kayu yang diberikan adalah jenis kayu yang di produksi, artinya bahwa kelak akan diambil kembali untuk dijadikan lembaran-lembaran plywood. Persoalan utamanya 
adalah bahwa perusahaan berkiblat pada bisnis yang berorientasi untuk mencari uang sebanyak-banyaknya, bukan hanya menyediakan amal. CSR bukan semata-mata dipandang sebagai wujud kepedulian sosial dan tanggung jawab moral perusahaan.

\section{HASIL DAN PEMBAHASAN}

Hasil penelitian ini menemukan bahwa PT XYZ dalam upaya melakukan tanggung jawab sosial mereka bukan hanya sekeder menjalankan tradisi namun juga karena tanggung jawab moral yang sudah menjadi kebiasaan yang ada di perusahaan.

Menelusuri Noema atas pelaksanaan CSR yang dilakukan oleh PT XYZ yang beroperasi di tengah-tengah masyarakat dan punya ikatan sosial memperlihatkan bahwa semua yang dilakukan adalah bentuk dari tanggung jawab moral seperti yang diungkap oleh Djalil (2013), serta Branco \& Rodriques (2008), yang menunjukkan bahwa "ada sesuatu" di dalam konsep CSR yang membuat perusahaan tidak terbebani, melainkan menerima dan mempraktikkan CSR secara sukarela. Pelaksanaan CSR yang dilakukan oleh perusahaan tersebut telah dirasakan oleh karyawan dan masyrakat yang ada disekitar perusahaan. Kesadaran perusahaan untuk peduli pada lingkungan di mana ia beraktivitas dan kepedulian itu diwujudkan dalam bentuk tanggung jawab sosial baik internal maupun eksternal perusahaan. Kesadaran ini memberikan makna bahwa perusahaan bukan lagi sebagai entitas yang mementingkan diri sendiri, tetapi juga sebagai entitas yang bertanggung jawab terhadap lingkungan sosial. Hal ini dibuktikan di mana perusahaan ini berdiri pada tahun 1982 dan sudah memulai dengan hal-hal yang sederhana seperti pemberian sumbangan untuk acara keagamaan atau perbaikan jalan untuk akses masyarakat lokal. Tradisi ini kemudian terus di jalankan hingga saat ini. Perbedaan yang paling mendasar, saat ini perusahaan menerapkan "tradisi" tersebut dalam kerangka program CSR perusahaan. Meskipun sebatas program yang merupakan tradisi perusahaan dan hanya bersifat kedermawanan sosial, namun hal ini tetap menjadi salah satu faktor yang menjadi pertimbangan bagi perusahaan untuk menerapkan program yang substansinya dipandang sebagai bentuk CSR.

Namun pada kenyataannya, kegiatan sosial yang dilakukan oleh perusahaan di atas memiliki motif lain. Kegiatan sosial yang dilakukan oleh perusahaan sarat dengan asas pertukaran "Do ut des" saya memberi supaya engkau memberi sejalan dengan hasil penelitian Juholin (2004), yang mengungkap bahwa tanggung jawab social (CSR) lebih cendrung sebagai orientasi bisnis. Hal ini bertentangan dengan yang di ungkap oleh Wibisono (2007), bahwa perusahaan harusnya secara sukarela melaksanakan tanggungjawab sosialnya tanpa maksud apapun, karena perusahaan merupakan bagian dari masyarakat dan oleh karenanya wajar bila perusahaan memperhatikan kepentingan masyarakat. CSR bukan semata-mata dipandang sebagai wujud kepedulian sosial dan tanggung jawab moral perusahaan, hal ini tercermin dari penuturan bapak AS di mana beliau melihat bahwa tanggung jawab sosial perusahaan itu adalah apa yang perusahaan keluarkan dan apa yang perusahaan dapatkan atas pengeluaran tersebut. Di satu sisi CSR dilihat sebagai sebuah konsep kedermawanan, pada sisi dilihat sebagai sebuah cara untuk meningkatkan kinerja bisnis. Melalui kepedulian terhadap komunitas dan karyawan perusahaan mengharapkan imbalan. Sangat kontradiksi dengan penelitian yang diungkap Graafland \& Bert (2006), bahwa moral sebagai motif yang lebih kuat kontribusinya terhadap CSR dibandingkan finansial. 


\section{SIMPULAN DAN SARAN}

Saat ini perusahaan cenderung berbondong-bondong melaksanakan tanggung jawab sosial mereka dengan berbagai macam motif yang ada di balik pelaksanaan tersebut. Ada yang melaksanakannya secara sukarela sebagai bentuk moralitas namun juga ada yang melaksanakannya karena untuk tujuan profit demi kelangsungan perusahaan. Tanggung jawab sosial harusnya tanpa pamrih, karena apa yang perusahaan hasilkan sebenarnya di dalamnya ada hak orang lain. Berangkat dari hal tersebut, maka sejatinya apa yang sudah menjadi hak masyarakat dan lingkungan diberikan dengan ikhlas dan tulus. Hanya saja saat ini CSR sulit untuk semata-mata dipandang sebagai bentuk amal yang hanya didasarkan pada kesadaran moral dan tanggung jawab sosial dari perusahaan, namun sebagian memandang CSR sebagai bentuk lain dari upaya perusahaan mengejar profit sebagaimana hakikat alamiah dari sebuah bisnis wajah profit di balik topeng moralitas dan etika responsibilitas kemanusiaan dan inilah yang kemudian mewarnai beberapa kegiatan CSR yang PT XYZ. Kesimpulannya, di satu sisi CSR dapat saja dilihat sebagai sebuah konsep kedermawanan, pada sisi lain dapat dilihat sebagai sebuah cara untuk meningkatkan kinerja bisnis. Melalui kepedulian terhadap komunitas dan karyawan perusahaan mengharapkan imbalan. Penelitian berikutnya diharapkan dapat menggali lebih dalam dari sudut pandang masyarakat dan penerima program CSR yang merasakan langsung dampak dari kegiatan sosial perusahaan sehingga data dan informasi bisa menjadi lebih utuh.

\section{DAFTAR PUSTAKA}

Bowen H. (1953). Social Responsibility of the Businessmen. Harper \& Rowe: New York

Branco C. \& Rodrigues L. (2008). Factors Influencing Social Responsibility Disclosure by Portuguese Companies. Journal of BusinessEthics, 83:685.

Burrel G. \& Morgan G. (1979). Sociological Paradigms and Organizational Analysis. New York: Ashgate Publishing Company.

Djalil S. (2013) Konteks Teoritis dan Praktis Corporate Social Responsibility. Jurnal Reformasi Ekonomi, Vol 4. No. 1 Hal.4.

Estes R. (2005). Tiranny of The Bottom Line. Jakarta : Gramedia Pustaka Utama.

Graafland J. \& Bert V. (2006). "Strategic and Moral Motivation for CSR". The Journal of Corporate Citizenship, Vol. 22. pp. 111-123

Gulsevim Y.G. \& Gokhan S.G. (2009). Corporate Social Responsibility Practices of the Texile

Firm Quted in Istabul Stock Exchange. International Journal of Business, Economics, Finance and Management Sciences.

Joyner B.E. \& Payne D. (2002). Evolution and Implementation A Study of Value, Business

Ethic and Corporate Social Responsibility. Journal of Business Ethics, 41:291-311.

Juholin E. (2004). For Business or the Good of All? A Finnish Approach to Corporate Social Responsibility. Journal Corporate Governance, vol. 4, n. 3.

Kuswarno E. (2009). Fenomenologi. Bandung: Widya Padjajaran

Mamulati I. (2016). Amal Usaha Sebagai Aset Ekonomi Berbasis Keummatan. Jurnal Seminar Nasional dan The $3^{\text {rd }}$ Call for Syariah Paper: Syariah Paper Accounting FEB UMS. 
Moeryadi D. (2009). Pemikiran Fenomenologi menurut Edmund Husserl. Dipublikasi oleh Jurnal Studi.Blogspot.

Miles M. B \& Huberman A. M. (1984). Qualitative Data Analysis: A Source Book or New Methods. Beverly Hills: Sage Publication.

Robins F. (2005). The fututre of corporate social responsibility, Asian Business \& Management, No. 4, 95-115.

Santana S. (2010). Menulis Ilmiah Metodologi Penelitian Kualitatif. Jakarta: Yayasan Pustaka Obor Indonesia.

Sugiyono. (2012). Memahami Penelitian Kualitatif. Bandung: CV. Alfabeta.

Sukoharsono E.G. (2010). Metamorfosis Akuntansi Sosial dan Lingkungan: Mengkonstruksi Akuntansi Sustainabilitas Berdimensi Spritualitas. Pidato Pengukuhan Jabatan Guru Besar dalam Ilmu Akuntansi Sosial dan Lingkungan Fakultas Ekonomi: Universitas Brawijaya.

Wibisono Y. (2007). Membedah Konsep dan Aplikasi CSR. Gresik: Fascho Publishing 